\title{
MIR10A Gene
}

National Cancer Institute

\section{Source}

National Cancer Institute. MIR10A Gene. NCI Thesaurus. Code C81757.

This gene is involved in the regulation of gene expression and plays a role in the development of chronic myeloid leukemia. 